Хмара B.B. Phraseological units with somatic tooth element in different structured languages. // European Journal of Literature and Linguistics. - «East West $\gg$ Association for Advanced Studies and Higher Education GmbH, Vienna, 2016. - c.93-96.

\title{
Phraseological Units with Somatic tooth Element in Different Structured Languages
}

Abstract: This article offers comparative analysis of Phraseological Units with somatic element tooth based on Russian, Ukrainian, German and English. The purpose of this article is to show semantic features, isomorphic and allomorphic traits in four linguistic cultures.

Keywords: a comparative analysis, linguoculture, Phraseological Units.

The present paper focuses on comparative analysis of phraseological units with somatic element tooth in English, German, Ukrainian and Russian languages to identify semantic means of picture of the world manifestation and highlight isomorphic and allomorphic features in four linguistic cultures. 112 phraseological units with somatic element tooth (12 - English, 32 - German, 44 - Ukrainian and 24 - Russian) have formed the empirical data of our research.

Cultural Studies is the science that shows close connection between culture and language. The study of the linguistic and cultural peculiarities of different languages gives us an opportunity to elucidate the processes of perception and reproduction of the cultural experience through the language means. One of the main functions of the language is that it accumulates all epic achievements in scientific, social and cultural life of the nation $[5,20]$. From this point of view we regard language as the main source of cultural information and a specific way of information transfer.

Cultural codes match archaic views of people. They are universal. So coding of the space has only national peculiarity and it is special for every national cultural communities $[4,62]$. There are such basic codes: somatic, zoo, space, 
time. One of the oldest codes of culture is somatic. It is connected with parts of the body $[1,16]$.

One of the ways how to represent somatic code is phraseological units with somatic element. By means of such phraseological units and proverbs the language accumulates the empirical, spiritual and historical experience of the nation. The practical value of the phraseology from the cultural point of view is determined by that fact that during the long history of its development language preserves only those examples which are of great importance to human perception and are closely connected with the models, stereotypes of the nation and culture $[6,155]$.

Investigations in the field of phraseology show the dependence of linguistic functioning on certain ethnic community activities and the role phraseological units with somatic element in the process of interpretation and accumulation the empirical, spiritual and historical experience [8, 237-238].

Contrastive analysis of phraseological units with somatic element of genetically distant languages allows finding similarities and differences in models, stereotypes and national-cultural peculiarities $[3,22]$. So, due to the contrastive analysis it becomes possible to research semantic features of phraseological units of given languages [2, 5-6].

Our investigation shows that the anthropocentric meaning reflected with the help of the somatic component in the phraseology comprises the following spheres: features of character, age, intellectual ability, feelings, emotions and others. Thus, we defined phraseological units with the somatic element teeth/Zahn/ зуби/зубы related to 4 languages and have isomorphic meanings: symbol of aggression and reaction to it: Eng.: armed to the teeth; to show one's teeth; an eye for an eye, a tooth for a tooth; Germ.: bis an die Zähne bewaffnet sein; Auge um Auge, Zahn um Zahn; die Zähne zeigen (weisen); Ukr.: cушити зуби; око за око, зуб за зуб; озброєний до зубів; Rus.: о́ко за о́ко, зуб за зуб; быть вооружённым до зубов; (о)скалить зубы; misspeaking words: Eng.: like pulling teeth; Germ.: etw. zwischen den Zähnen murmeln; Ukr.: u̧idúmu (nроціiúmu) крізь зуби; крізь зуби точити; Rus.: сквозь зубь говорить (сказать); 
exercising self-control and patience: Eng set one's teeth; Germ.: mit zusammengebissenen Zähnen (etw. tun); die Zähne zusammenbeißen; Zahn auf Zahn beißen; Ukr.: зиіпити (стиснути, склепити) зуби; Rus.: сжать (стиснуть) зубыл; very little amount of smth.: Eng (as) scarce as hen's teeth; Germ.: das ist (reicht, geht) auf den hohlen Zahn; das ist nur auf aбо für den hohlen Zahn; Ukr.: на один зуб; на одно́го зубба; Rus.: на один зуб.

Other common groups of phraseological units with somatic element teeth/ зуби/зубь include:

- experience (in English, Ukrainian and Russian): Eng.: cut one's teeth in (on) smth.; Ukr.: зуби на чому стерти (з '̈сти); Rus.: съесть зубы на чём;

- anger (in German, Ukrainian and Russian): Germ.: einen Zahn auf ( gegen, wider ) j-n haben; Ukr.: скреготати (скреготіти, скрипіти, скрипотіти) зубами; гострити зуби; Rus.: скрежетать зубами; точить зуб (зубы); failing in solving complex task: Germ.: sich (D) an etw. (D) die Zähne ausbeißen (ausbrechen, stumpf beißen); Ukr.: горімок не по зуба́х; обламати зуби; збутися зубів; не про зуби; Rus.: облома́ть себе́ зуббы; лишиться зубов; не по зубам; не по зубам мне эти орешки; to tremble because of cold or fear: Germ.: mit den Zähnen klappern; Ukr.: дзвони́ти зуба́ми; зуб на зуб не попадає; кла́иати зубами; вибивати зуба́ми чечітку; Rus.: зуб на зуб не попадает; стучать зубами;

- gossips (in German and Ukrainian languages): Germ.: $j$ - $n$ durch die Zähne ziehen; j-n zwischen den Zähnen haben; Ukr.: бра́ти на зуби; зав'язнути в зуби; перетирати на зубах;

- hunger (in Ukrainian and Russian languages) : Ukr.: кла́сти (покласти) зу́би на полицюо (на мисник); (i) на зуб ніччого покласти; на зуб нічого покласти; Rus.: зубы на полку (класть); на голодные зубы; to divert with the help of conversation: Ukr.: замовляти зуби; зубы заговаривать; to have negative life expirience: Ukr.: пройти мідні труби $і$ чортові зуби; Rus.: прошел огни, воды, медные трубы, попадал к черту в зубы и то вымел. 
The comparative analysis of phraseological units with somatic element teeth/Zahn in English and German also enabled us to distinguish isomorphic meanings: to work good and quickly: Eng.: get teeth into the job; Germ.: einen Zahn zulegen.

Allomorphic meaning of the phraseological units with the somatic element teeth include:

age (in the English language): Eng.: long in the tooth; falsehood: Eng.: lie in one's teeth; desire to eat many sweet foods: Eng.: have a sweet tooth; to make bad influence on others: Eng.: rotten tooth injures its neighbours; to take some action that is intended to prevent strife or trouble: Eng.: sow dragon's teeth;

death (in the German language): Germ.: $j$-m tut kein Zahn mehr weh; disappointing: Germ.: $j$-m den Zahn ziehen; eat without appetite: Germ.: die Zähne (hoch) heben; lange Zähne machen; mit langen Zähnen essen; to be able to protect one`s points of view: Germ.: $j$-d hat scharfe Zähne; destructive hand of time: Germ.: der Zahn der Zeit; tipped the girl: Germ.: j-m einen Zahn abschrauben; to check someone: Germ.: $j-m$ auf den Zahn fühlen; warming to keep silence: die Zähne sollen dir ausfallen!; request not to think about nonsense: Germ.: diesen Zahn laß dir ziehen (або ausziehen)!.

smile (in the Ukrainian language): Ukr.: торгувати зубами, світити зубами; risk: Ukr.: до дідька в зубб; responsible for the actions of others people: Ukr.: Адам з'їв кисличку, а у нас оскома на зубах; psychological condition when a person uncontrolled emotions and actions: Ukr.: хоч зуби рви; detect excessive indulgence, starch: Ukr.: дивитися в зуби;

unwillingness to lose smth. (in the Russian language): Rus.: зубами держаться; desire to eat: Rus.: разгорелись зубыл. Allomorphic meanings of the Phraseological Units with the somatic element $\underline{3 y \sigma}$ are:

So, phraseological units with somatic element have isomorphic and allomorphic features in English, German, Ukrainian and Russian languages. It has been shown that phraseological units with the somatic element teeth/Zahn/зуби/зубы in English, German, Ukrainian and Russian languages have 
such negative meanings: symbol of aggression, misspeaking words, very little amount of smth.; and positive: exercising self-control and patience. In addition, phraseological units with somatic element teeth/зуби/зубы have positive meaning experience in English, Ukrainian and Russian languages.

Phraseological Units with somatic element Zahn/зуби/зубы German, Ukrainian and Russian languages have such common negative meanings as anger, to tremble because of cold or fear, failing in solving complex task.

Special meaning for English and German Phraseological Units is to work good and quickly; for German and Ukrainian are gossips. Ukrainian and Russian phraseological units with somatic element зуби/зуббы have such negative meanings as hunger, negative life experience, to divert with the help of conversation.

Allomorphic features of the phraseological units with the somatic element teeth in the English language with negative meanings include: to take some action that is intended to prevent strife or trouble, falsehood, to make bad influence on others; and neutral: desire to eat many sweet foods.

Phraseological Units with the somatic element Zahn in the German language demonstrate specific negative meanings: death, disappointing, eat without appetite, warming to keep silence, tipped the girl, destructive hand of time; and positive: request not to think about nonsense, to be able to protect one 's points of view, to check someone.

Phraseological units with the somatic element $3 y \sigma$ in the Ukrainian language demonstrate specific negative meanings: responsible for the actions of others people, psychological condition when a person uncontrolled emotions and actions, detect excessive indulgence, starch; and positive: smiling.

Phraseological units with the somatic element $3 y \sigma$ in the Russian language designate specific positive meanings: unwillingness to lose smth and desire to eat.

Thus, contrastive analysis of Phraseological units in different languages irrespective of their origin is topical as it allows singling out allomorphisms and isomorphisms in the systems of Phraseological units with the somatic element in 
order to specify positive and negative associations which lie under nomination in different languages.

The perspective of the investigation lies in the contrastive analysis of Phraseological units with other somatic elements in East Slavic and West Germanic languages from the standpoint of lingocultural studies.

\section{References}

1. Гудков Д. Б. Телесный код русской культуры: материалы к словарю / Д. Б. Гудков, М. Л. Ковшова. - М. : Гнозис, 2007. - 288 с.

2. Ибрагимова И.И. Сопоставительное исследование соматических фразеологизмов (на мат англ.и тат. яз.): Автореф. дис. ... канд. филол. наук: 10.02.19 - теория язика. - Казань, 1993. - 23 с.

3. Кашкин В. Б. Подходы к сходствам и различиям языков в истории языкознания. - Воронеж: Изд-во ВГТУ, 1999. - С. 4-31.

4. Ковшова М. Л. Анализ фразеологизмов и коды культуры // Известия РАН. Серия литературы и языка. - 2008. - Т. 67, № 2. - С. 60-65.

5. Маслова В.А. Введение в лингвокультурологию / В.А. Маслова. M., 1997. - 207 c.

6. Скоробагатько Н. О. Фразеологічна соматика в дзеркалі архетипних уявлень людини / Н. О. Скоробогатько // Лінгвістика : [зб. наук. праць]. - Луганськ : Альма-матер, 2008. - № 1 (13). - С. 154-159.

7. Шевелюк В. А. Соматичний компонент як основа утворення вторинно-образного значення фразеологізмів в іспанській та українській мовах / В. А. Шевелюк // Проблеми зіставної семантики : [зб. наук. ст.]. Вип. 6. - К. : Вид. центр КНЛУ. - 2003. - 474 с. - С. 236-241.

\section{Lexicographical sources}

8. Гаврись В.І. Німецько-український фразеологічний словник / B.I. Гаврись, О.П. Пророченко. - К. : Радянська школа, 1981. - Т 1. - 416 с.

9. Гаврись В.I. Німецько-український фразеологічний словник / B.I. Гаврись, О.П. Пророченко. К. : Радянська школа, 1981. - Т 2. - 382 с. 
10. Словопедія. Фразеологічний словник української мови [Електронний ресурс]. - Режим доступу: URL: http://slovopedia.org.ua/49/53407/ 359960.html. - Назва з екрана.

11. Ужченко В.Д. Фразеологічний словник української мови / В.Д. Ужченко, Д.В. Ужченко. - К. : Освіта, 1998. - 224 с.

12. Фёдоров А. И. Фразеологический словарь русского литературного языка / А. И. Фёдоров. - Москва: АСТ, 2008. - 880с.

13. Apperson G.L. The Words worth Dictionary of Proverbs / G.L. Apperson. - Wordsworth Reference, 1993. - 721 p

14. The free dictionary [Electronic Resource]. - Mode of access: URL: www.thefreedictionary.com 